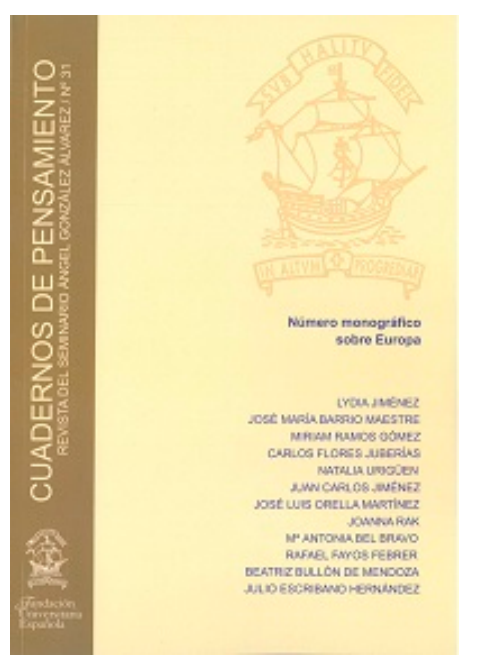

Cuadernos de Pensamiento $\mathrm{N}^{\circ} 31$ NÚMERO MONOGRÁFICO SOBRE EUROPA Año: 2018 DOI: https://doi.org/10.51743/cpe.46

\title{
Discoursive Self-Legitimation of Gals for Gals as the Movement's Collective Identity-Forming Factor
}

\author{
El discurso de autolegitimización como factor de formación de la \\ identidad colectiva en el movimiento Dziewuchy Dziewuchom
}

JOANNA RAK

Faculty of Political Science and Journalism

Adam Mickiewicz University, Poznań

RESUMEN: En este artículo sobre "El discurso de autolegitimización como factor de formación de la identidad colectiva en el movimiento Dziewuchy Dziewuchom" se profundiza analíticamente en el pensamiento político del movimiento polaco Dziewuchy Dziewuchom, que surgió para oponerse al proyecto de ley presentado, que proponía una prohibición total del aborto, durante el periodo 2016-2018. Su objetivo es determinar cómo Dziewuchy Dziwuchom explicó y justificó su iniciativa y actividad política, cómo las estrategias de este discurso de auto-legitimación cambió con el tiempo y en qué medida el proceso de formación de su identidad colectiva dependió de los incentivos externos recibidos en las etapas de dos procesos legislativos. Al emplear el análisis de fuentes escritas, el análisis de contenido relacional y la tipología de estrategias de legitimación discursiva, la investigación descubre que el movimiento realizó tentativas de formación de una identidad directamente después de la movilización masiva y durante el primer aniversario de su fundación, en lugar de someterse a las iniciativas de los procesos legislativos. La identidad de Dziewuchy Dziewuchom constantemente se basaba principalmente en la personalización, la

\footnotetext{
* This paper is a result of the research project The Culture of Political Violence Dynamics of Anti-austerity Movements in Europe. It was financially supported by the National Science Centre, Poland [grant number 2016/23/D/HS5/00192].
} 
reflexión y la comunicación en las redes. La fase de personalización dominó al principio, pero luego esta estrategia dio lugar a la de reflexión. Inicialmente, Dziewuye Dzeiwuchom se enfocó en vincular el movimiento con celebridades y los derechos humanos, y luego en la preservación de sus puntos fuertes para obtener apoyo social y simpatías. Lo siguiente será la reflexión para dotar a los activistas con argumentos contra la situación política actual y la legislación prevista. Sin embargo, la necesidad de organización no entró en el discurso, lo que revela la ausencia de aspiraciones para construir un movimiento duradero.

PALABRAS ClAVE: Violencia política, movimiento social, política contenciosa, protesta, pensamiento político polaco

ABSTRACT: The article delves analytically into the political thought of the Polish pro-choice movement Gals for Gals which arose to oppose to the submitted draft act which was to have imposed a total ban on abortion and acted in 2016-2018. It aims to determine how Gals for Gals explained and justified their occurrence and political activity, how the strategies of this discoursive self-legitimation changed over time, and to what extent the collective identity-forming process depended on the external incentives understood as the stages of two legislative processes. In employing the written sources analysis, relational content analysis, and the typology of discoursive legitimation strategies, the research discovers that the movement made identityforming attempts directly after the mass mobilization and over the first anniversary of foundation rather than subjected the attempts to the legislative processes. The Gals' identity constantly drew upon mostly authorization, rationalization, and remotely narrativization. Authorization dominated at the beginning, but then this strategy gave place to rationalization. Initially, the Gals focused on linking the movement to celebrities and human rights, and then consequently preserved the links to gain social support and appreciation. Rationalization armed activists with arguments against the current political situation and the planned legislation. Moralization did not enter the discourse, which reveals the absence of aspirations to build an enduring movement.

KEYWORDS: Political violence, social movement, contentious politics, protest, Polish political thought 


\section{INTRODUCTION}

Tn Poland, abortion is already banned in almost all circumstances. The three current exceptions are when the woman's life is in jeopardy, there is a risk of serious and irreversible damage to the fetus, the pregnancy is as a result of rape or incest confirmed by a prosecutor ${ }^{1}$. On 1st April 2016, the mass media broadcast the news about the draft novelty of the Polish Abortion Law which was to have imposed a total ban on abortion. That day, social activists launched the Facebook Action Group "Gals for Gals" (in Polish "Dziewuchy Dziewuchom"), and then the official website, to manifest their opposition towards the planned legislation and to gain social support. The grassroots women's social media initiative was the trigger point for the new protest movement, Gals for Gals, although the founders maintained and constantly emphasized that their collective action was not a movement but the Facebook Action Group. Despite the claim, under the Gals for Gals label, about 100000 mostly women but also men of all ages protested. They demanded the right to choose for every woman in Poland ${ }^{2}$.

Noteworthy, political action of those using the label met the essential features of social movements rapidly after the use of the first forms of protest $^{3}$. It means that Gals for Gals became conscious, collective, and organized efforts at a social change, here, at the rejection of a total ban on abortion. Their initiatives were not one-off events. Instead, Gals for Gals existed over some span of time by engaging in a conflictual issue with a particularly powerful opponent, here, Polish legislative body and

${ }^{1}$ BBC, "Black Monday: Polish women strike against abortion ban", in $B B C$ October 3, 2016, [electronic version]. Available: https://www.bbc.com/news/world-europe-37540139 [accessed October 11, 2018].

${ }^{2}$ Gals for Gals, Dziewuchy Dziewuchom: O nas, Warszawa 2016, [electronic version]. Available: https://www.dziewuchydziewuchom.pl/ [accessed October 11, 2018].

${ }^{3}$ The essential features of social movements are elaborated by drawing on: G. EDWARDS, Social Movements and Protest, Cambridge University Press, Cambridge and New York 2014, 4 . 
government. Movement participants worked together to resist a condemned social change. They shared a collective identity and actively strove to foreclose their expected social situation by employing protest.

The movement used contentious performances, the forms of protest defined as standardized ways in which one set of political actors makes collective claims on some other set of political actors ${ }^{4}$. During mass mobilization, activists formed special-purpose associations and coalitions in big cities (e.g., Warszawa, Kraków, Poznań, Łódź, Wrocław, Szczecin, Katowice), held public meetings, solemn processions, marches, the first one was "Black Monday" (in Polish "Czarny Poniedziałek"), others were called "Black Protests" (in Polish "Czarne Protesty"), vigils, rallies, strikes, e.g., "All-Polish Women's Strike" (in Polish "Ogólnopolski Strajk Kobiet”), petition drives, made statements to and in public media, undertook activities in commercial and social media, e.g., published selfies in black clothing in social media, tagged \#czarnyprotest (\#blackprotest), gave performances, made rough music (the so-called shivarees), displayed posters, and distributed pamphlets ${ }^{5}$. Demonstrations were staged in solidarity with Poles in other European cities, including Berlin, Brussels, Dusseldorf, Belfast, London, and Paris ${ }^{6}$. Apart from the modular contentious performances, Gals for Gals used innovations. Activists protested by sending clothes hangers, as the symbol of illegal abortion ${ }^{7}$, to the Prime Minister Beata Szydło who supported the delegalization of abortion ${ }^{8}$, calling the representatives of the

${ }^{4}$ Ch. Tilly, S. Tarrow, Contentious Politics, 2nd edition, Oxford University Press, New York 2015, 14; CH. Tilly, Contentious Performances, Cambridge University Press, Cambridge, New York, Melbourne, Madrid, Cape Town, Singapore, São Paulo, and Delhi 2008, 13.

${ }^{5}$ K. Jacobsson, E. KorolczuK, "Preface", in K. Jacobsson, E. KorolczuK (eds.), Civil Society Revisited: Lessons from Poland, Berghahn Books, Oxford, New York 2017, p. ix. See the description of Gals for Gal's social mobilization: E. KOROLCZUK, "Explaining mass protests against abortion ban in Poland: the power of connective action", in Zoon Politikon, 7, (2016), 91-113.

${ }^{6} \mathrm{BBC}$, o. c.

${ }^{7}$ Gals for Gals, Wyślij wieszak pani premier, April 4, 2016, [electronic version]. Available: https://www.dziewuchydziewuchom.p1/2016/04/04/wyslij-wieszak-pani-premier/ [accessed October 24, 2018].

${ }^{8}$ H. GALSIOROWSKA, "Women and their Rights in the Nationalists' Strategies: Abortion as a Contentious Issue in the Polish 'Culture War'”, in M. Fielitz, L. L. LALOIRE (eds.), 
state apparatus and sending them emails to inform about own ovulation and menstrual period ${ }^{9}$.

The Abortion Law has not been implemented until now, but committees of the Sejm of the Republic of Poland are working at its amendment ${ }^{10}$. It is, however, the result of the social activities of not only Gales for Gales but many other political subjects, including political parties which decided against the change of law. Since January 2018, the reproductive rights have not been widely discussed in the mass and social media anymore. Additionally, in April 2018, Agata Maciejewska, the author of the Gals for Gals' name, restricted the name as a trademark, which drew criticism from the existing supporters, split up activists, and held them back from using their current identity on the Internet and during protests ${ }^{11}$. When Facebook administrators deleted accounts, groups, and fan pages of local groups, the movement lost the most valuable resources, the lists of activists and tools for dissemination of information. Simultaneously, from April 2016 to April 2018, the support on Facebook for the original fan page considerably declined from 100000 to 41000 likes $^{12}$. The turnout and participation in contentious performances mirrored the number and sharp drop in the likes. Although Gals for Gals ceased to organize collective actions before 12th April 2018, and still run the Facebook Action Group, this date may be considered the end of the movement's public activity and the moment of

Trouble on the Far Right: Contemporary Right-Wing Strategies and Practices in Europe, Verlag, Bielefeld 2016, 137.

9 Gals for Gals, \#TrudnyOkres, April 4, 2016, [electronic version]. Available: https://www.dziewuchydziewuchom.p1/2016/04/04/trudnyokres/ [accessed October 24, 2018].

${ }^{10}$ Wprost and TVP Info, "Sejm skierował projekt 'Zatrzymaj aborcję' do dalszych prac w komisjach", in Wprost January 10, 2018, [electronic version]. Available:

https://www.wprost.pl/kraj/10097241/sejm-skierowal-projekt-zatrzymaj-aborcje-dodalszych-prac-w-komisjach.html [accessed October 11, 2018].

11 B. GODZIŃSKI, “'Dziewuchy dziewuchom' oficjalnie znakiem towarowym. Inicjatorka ruchu grozi feministkom sądem”, in Na Temat April 21, 2018, [electronic version]. Available:

https://natemat.pl/236271,konflikt-wsrod-feministek-dlaczego-dziewuchy-dziewuchom-

kloca-sie-o-nazwe [accessed October 11, 2018].

${ }^{12}$ K. Jacobsson, E. KorolczuK, o. c., ix; Gals for Gals, Co robimy?... o. c. 
social demobilization because then they published the last news on their official website.

The participants of Gals for Gals created their collective identity by distributing and redistributing political thought drown from the official website in spite of the demarcation line determined between the movement and its name determined by the founders. Even though the founders did not want to contribute to the movement directly, they underlay social mobilization, inspired contentious performances, and informed the movement's way of justifying and accounting for their claims. It is unclear, however, how and to what extent the semantic structures distributed with the website in the course of public discussion on the right to choose allowed activists to shape their collective identity and become the movement.

The current specialist literature on Gals for Gals concentrates on the history of the movement, its goals, claims ${ }^{13}$, structure $^{14}$, contentious performances during mass mobilization ${ }^{15}$, relations between the movement and other political subjects ${ }^{16}$, posters and slogans used during contentious performances ${ }^{17}$, locates the movement in the history of abortion ${ }^{18}$ as well as among anti-capitalist projects in Poland and other states, links the women's protests to movements opposing austerity, environmental despoliation, precarization, and nationalism ${ }^{19}$. Although these works shed considerable

13 A. WierzChOlSKA, "Gender in the resurgent Polish conservatism", in K. BLUHM, M. VARGa (eds.), New Conservatives in Russia and East Central Europe, Routledge, London, New York 2018, 198-222.

${ }^{14}$ D. V. POLANSKA, "Polish citizens turn their back on NGOs and embrace community activism", in The Conversation, 3/3, (2017), 1-4. [electronic version]. Available: http://www.diva-portal.org/smash/get/diva2:1115214/FULLTEXT01.pdf [accessed October $11,2018]$.

${ }^{15}$ E. KorolCZUK, o. c.

16 T. Beaty, "Strike to Win: Can Polish Feminists Turn Protest Into Power?", in Dissent, 64/3, (2017), 125-133.

17 A. KiEŁBIEWSKA, "Retoryka 'czarnego marszu' na materiale haseł prezentowanych w przestrzeni publicznej”, in Res Rhetorica, 5/3, (2018), 2-21.

${ }^{18}$ K. BielinsKa-KowalewsKa, “\# czarnyprotest: The Black Protest for Abortion Rights in Poland", in New Politics, 16/2, 2017, 53.

${ }^{19}$ M. Kaletzky, R. Mcglazer, "Migrating Tactics: An Interview with Ewa Majewska and Katarzyna Rakowska", in Critical Times: Interventions in Global Critical Theory, 1/1, 
light on the movement's nature and broad historical, political, economic, social, and cultural context it acted, they tell little about Gals for Gals' contention- and identity-forming political thought. This article endeavors to contribute to the specialist literature on social movements and our knowledge of the movement's discursive self-legitimation by analyzing semantic structures distributed on the Gals for Gals' website. It aims to identify the types of Gals for Gals' discoursive self-legitimation strategies during mass mobilization and account for their role in the process of the movement's collective identity creation along with the Polish Parliament works on the restriction of abortion law.

\section{METHODOLOGICAL AND THEORETICAL ASSUMPTIONS FOR THE RESEARCH}

This research is not paradigm-driven. Instead, it adopts a pragmatic ontological perspective which shows the political reality as incessantly negotiated and renegotiated more than constant and fixed. It also uses a pragmatic epistemological point of view to obtain intersubjectively the verifiable research conclusions by formulating and following theoretical and methodological assumptions. It avoids a "methodolatry" trap by choosing the pragmatic methodological perspective $e^{20}$, which means employing the set of methods, techniques, and tools to address research problems.

The research problems are: how did Gals for Gals explain and justify their occurrence and political activity? How did the strategies of this discoursive self-legitimation change over time? And to what extent did the collective identity-forming process depend on the external incentives? The first focuses on the identification of the strategies of discoursive selflegitimation. Legitimation is defined as a widespread acknowledgment of the legitimacy of explanations and justifications for how something is and how it

2018, 226-240. Available: https://ctjournal.org/index.php/criticaltimes/article/view/21 [accessed October 11, 2018].

${ }^{20}$ J. RAK, Theorizing Cultures of Political Violence in Times of Austerity: Studying Social Movements in Comparative Perspective, Routledge, London and New York 2018, 8. 
is done ${ }^{21}$. It takes place through discourse understood as a way of representing aspects of the world with language ${ }^{22}$. Since much of the work of legitimation is through discourse, textual analysis can distinguish and examine various strategies of legitimation (e.g., through narrative or by reference to authority or utility $)^{23}$. Here, discoursive strategies of selflegitimation are ways of using specific discourses to account for and justify own existence and political actions and thereby create a sense of their legitimacy.

Whereas the first problem allows us to identify the configurations of the types of discoursive self-legitimation strategies, the second is to discover their reconfigurations which went along the legislative processes initiated by the two draft acts of the Law on Family Planning, Human Embryo Protection, and Conditions of Permissibility of Abortion: Act of January 7, 1993, as amended as of December 23, $1997^{24}$ which were to have tightened up the law. So, the second research problem makes use of comparative analysis and deals with the changes in the strategies of discursive selflegitimation during Gals for Gals' mass mobilization, the subsequent phases of contention which led to social demobilization.

While the first two research problems are exploratory, the third is of explanatory nature. It enables us to explain the relations between the process of building Gals for Gals' collective identity and the external incentives. It shows the identity-forming strength of the incentives by dealing with their impact on the discoursive self-legitimation strategies. The external incentives, which are the critical junctures for the movement's continuance, are as follows: social mobilization, the submission, the first, and the second reading of the first draft act which was to have imposed a total ban on

${ }^{21}$ N. Fairclough, Analysing Discourse: Textual Analysis for Social Research, Routledge, London and New York 2003, 219.

${ }^{22}$ Ibid., 215.

${ }^{23}$ Ibid., 219.

${ }^{24}$ See the text of law in Polish and English (unofficial translation): Center for Reproductive Rights, Law on Family Planning, Human Embryo Protection, and Conditions of Permissibility of Abortion Act of January 7, 1993, as amended as of December 23, 1997, New York 2018, [electronic version]. Available: https://www.reproductiverights.org/world-abortionlaws/polands-abortion-provisions [accessed October 10, 2018]. 
abortion, the submission and the first reading of the second draft act on the same subject, and social demobilization. The elements of the legislative processes were the threat situations for the values held by the participants of the movement. For the sake of clarity, the research focuses on the awareness level rather than the movement's institutionalization.

Although the research goes on qualitative analysis, the methodological assumptions contain research hypotheses. Nevertheless, they are highly general not to exact an interpretation-orientation on the researcher and up to a point rigorous to give an analysis direction. Predicted answers to the research problems draw upon the review of literature on discursive legitimation ${ }^{25}$ and preliminary recognition of empirical data.

As the hypotheses assume, Gals for Gals might have explained and justified their occurrence and political activity with the strategies of discoursive self-legitimation: authorization, moral evaluation, rationalization, and mythopoesis. On the awareness level, they might have built a sense of legitimacy on authorization-derived human rights, moral evaluation-derived value systems, rationalization-derived social knowledge, and mythopoesis-driven stories about social justice to provide themselves with cognitive validity. The strategies might have co-existed and been developed before the first and the second reading of the first draft act which was to have imposed a total ban on abortion and the first reading of the second draft act on the same subject. These external incentives might have influenced the discoursive self-legitimation strategies. They might have become the collective identity-forming factor regardless of the founders' resistance because the strategies, which occurred as the responses to the critical junctures, offered internally coherent and rough-and-ready justifications and explanations against the restriction of abortion law.

${ }^{25}$ R. Suddaby, R. GREENWOOd, "Rhetorical Strategies of Legitimacy", in Administrative Science Quarterly, 50/1, 2005, 35-67; E. VAARA, "Struggles over legitimacy in the Eurozone crisis: Discursive legitimation strategies and their ideological underpinnings", in Discourse \& Society, 25/4, 2014, 500-518; T. VAN LEEUWEN, "Legitimation in discourse and communication", in Discourse \& Communication, 1/1, 2007, 91-112; T. VAN LEEUWEN, Discourse and Practice: New Tools for Critical Discourse Analysis, Oxford University Press, New York 2008. 
The research makes use of the method of written sources analysis to solve the research problems. It derives texts from Gals for Gals' official website ${ }^{26}$. The elements of discoursive self-legitimation are in the following sections of the website: Statement of Collective Identity ${ }^{27}$, Manifesto ${ }^{28}$, Statute of Gals for Gals' Group ${ }^{29}$, \#sexedpl Announcement ${ }^{30}$, \#PopieramDziewuchy (\#ISupportTheGals - translated by the author) Announcement ${ }^{31}$, and the news published from the social mobilization and the first news announcement on the website on 1st April 2016 to 12th April 2018, the movement's demobilization and publication of the last news on the website $^{32}$. The website was the main vehicle for the distribution of the Gals for Gals political thought. The Facebook Action Group only redistributed the semantic structures used by the movement to legitimize themselves. Currently, it serves to comment on selected news from Poland and abroad. Importantly, the involved period encompasses the current legislative processes concerning Law on Family Planning, Human Embryo Protection, and Conditions of Permissibility of Abortion: Act of January 7, 1993.

The study employs the technique of relational content analysis to identify and interpret relationships between the concepts used by Gals for Gals to account for and justify their existence and political actions. It does duty to establish what meanings result from grouping semantic structures. The basic

\footnotetext{
${ }^{26}$ Gals for Gals, Dziewuchy Dziewuchom: O nas, Warszawa 2016, [electronic version]. Available: https://www.dziewuchydziewuchom.pl/ [accessed October 11, 2018].

${ }^{27}$ Gals for Gals, Co robimy?... o. c.

${ }^{28}$ Gals for Gals, Manifest: Przemówienie Dziewuch odczytane na demonstracji, Warszawa 2016, [electronic version]. Available: https://www.dziewuchydziewuchom.pl/onas/manifest/ [accessed October 11, 2018].

${ }^{29}$ Gals for Gals, Regulamin Grupy Dziewuchy Dziewuchom, Warszawa 2016, [electronic version]. Available: https://www.dziewuchydziewuchom.pl/o-nas/regulamin-grupydziewuchy-dziewuchom/ [accessed October 11, 2018].

${ }^{30}$ Gals for Gals, \#sexedpl Announcement, Warszawa 2016, [electronic version]. Available: https://www.dziewuchydziewuchom.pl/sexedpl/ [accessed October 11, 2018].

${ }^{31}$ Gals for Gals, \#PopieramDziewuchy Announcement, Warszawa 2016, [electronic version]. Available: https://www.dziewuchydziewuchom.pl/popieramdziewuchy/ [accessed October 11, 2018].

32 Gals for Gals, News, Warszawa 2016-2018, [electronic version]. Available: https://www.dziewuchydziewuchom.pl/news/ [accessed October 11, 2018].
} 
analytical tool employed to scrutinize the structures contributing to the strategies of self-legitimation is Theo van Leeuwen's typology of legitimation $^{33}$. It involves authorization, moral evaluation (moralization), rationalization, and mythopoesis (narrativization). According to $T$. van Leeuwen, authorization is legitimation by reference to the authority of tradition, custom, law, and persons in whom institutional authority is vested. Moral evaluation is legitimation by reference to value systems. Rationalization draws on the utility of beings, phenomena, and processes. It is legitimation by reference to the objectives and uses of institutionalized social action and the knowledge that society has produced to provide them with cognitive validity. Finally, mythopoesis is legitimation expressed through narratives whose results reward legitimate deeds and punish nonlegitimate deeds ${ }^{34}$.

For each type of strategy, the study adopts the set of qualitative indicators developed by Olga Lavrusheva but purges it of specific references to the original author's research field and fortifies the lists of indicators with others to cover the strategies' whole semantic fields ${ }^{35}$. Authorization may be either personal or impersonal. Whereas the former is by references to public figures, analysts, and experts, the latter is by references to the government, governmental bodies and departments, planning guidance, speech notes of official authority representatives, the court, and the law. Apart from O. Lavrusheva's indicators of impersonal authorization, the study involves references to custom, habit, tradition, practice, states, awards, and organizations. As O. Lavrusheva assumes, the features of authorization are references to authorities, negative tone, direct quotes, and critical tone ${ }^{36}$. However, since the tones and quotes are not indicative, the indicators of authorization are just the references to personal and impersonal authority regardless of their vein. In O. Lavrusheva's approach, the methods of the strategy's application are presentation of various opinion on the change,

\footnotetext{
${ }^{33}$ T. VAN LeEUWEn, Discourse and Practice... o. c., 105-106.

${ }^{34}$ Ibid.

${ }^{35}$ O. Lavrusheva, Discursive Legitimation Strategies in The Media: Case Study of the UK Retail Planning Policy, Aalto University, School of Business, Aalto 2013, 43-66.

${ }^{36}$ Ibid., 54.
} 
support of impersonal authorization by personal statements of influential official authorities, the contrast of opinions and voices, comments criticizing decisions of the government ${ }^{37}$.

According to O. Lavrusheva, the features of moralization are references to values, moral basis, and emotional elements. The methods of moral evaluation's application are the highlight of moral values or main public concerns, the overview of beneficial practices, revealing indirect values related to the change, criticism of practices, opposing attitudes for and against the change, statements of related area specialists ${ }^{38}$.

O. Lavrusheva points out that the features of rationalization legitimation are references to the utility or function of an action, common sense as a basis, rational explanations, and requests for further explanations $^{39}$. Worth adding to the list are knowledge produced by society, institutionalized social action, and informed natural order of things. In O. Lavrusheva's framework, the methods of its application are the overview of past practices' consequences, criticism of earlier applied actions, examples of already implemented beneficial practices, projection of possible future benefits, opposition of various parties' attitudes, reference to open opinion or knowledge of influential persons, research, and analyses findings ${ }^{40}$.

O. Lavrusheva establishes the following features of narrativization: reference to stories, time scope, entertaining tone, dramatization, certain exaggeration, and lengthy texts ${ }^{41}$. Nevertheless, the last four qualities are not typical for the strategy and thus ruled out from the list as nonindicative. In O. Lavrusheva's model, the methods of mythopoesis's application are evolution within the time, historical summary of past events related to the change, presentation of past practices as a support for new similar or related development or to stress the need for a change, projection of future outcomes or behavior influenced by changes, forecast

\footnotetext{
${ }^{37}$ Ibid.

${ }^{38}$ Ibid., 63.

${ }^{39}$ Ibid., 49.

${ }^{40} \mathrm{Ibid}$.

${ }^{41}$ Ibid., 59.
} 
of the change's consequences, comparison among past and present or future to justify the change ${ }^{42}$.

\section{MEASUREMENT AND ANALYSIS OF Discoursive SELF- LEGITIMATION}

This part of the article applies the methodological and theoretical assumptions to the empirical analysis and introduces the research results. The first period covered with the analysis is from 1st April 2016 to 18th August 2016. These caesurae are the Gals to Gals mobilization and the day before the submission of the first draft act which was to have imposed a total ban on abortion in Poland ${ }^{43}$. In this period, the founders used discoursive self-legitimation strategies more frequently than in others, namely 73 times. They took form of authorization (50.68\%), rationalization $(46.58 \%)$, and narrativization $(2.74 \%)$. The moral evaluation did not appear in the movement's discourse. The configuration indicates that the founders searched for and introduced personal and impersonal authorities to justify and account for Gals for Gals' occurrence and actions. They wanted to create links between the socially accepted beings, phenomena, and processes and the newly created movement to gain social support and appreciation. The rationalization was also a frequently utilized strategy to arm the participants with the arguments for taking part in contentious performances. The narrativization served as a tool for locating Gals for Gals in the history of

\footnotetext{
${ }^{42}$ Ibid., 59.

${ }^{43}$ The dates of the legislative processes' stages come from: Sejm RP, Obywatelski projekt ustawy o zmianie ustawy z dnia 7 stycznia 1993 r. o planowaniu rodziny, ochronie plodu ludzkiego $i$ warunkach dopuszczalności przerywania ciaży oraz ustawy z dnia 6 czerwca 1997 r. - Kodeks karny, Warszawa 2016, [electronic version]. Available: http://www.sejm.gov.pl/sejm8.nsf/PrzebiegProc.xsp?id=6EDFF98AE25263E5C125801400 298427 [accessed October 22, 2018]; Sejm RP, Obywatelski projekt ustawy o zmianie ustawy z dnia 7 stycznia 1993 r. o planowaniu rodziny, ochronie plodu ludzkiego $i$ warunkach dopuszczalności przerywania ciaży, Warszawa 2018, [electronic version]. Available:

http://www.sejm.gov.pl/sejm8.nsf/PrzebiegProc.xsp?id=CDD22B469F73D121C125820B0 057A399 [accessed October 22, 2018].
} 
Poland and thus determining its particular importance for Poles. The lack of moralization reveals no aspirations and inability to build an enduring movement.

In the first period, impersonal authorization was by the references to women freedom, human rights, reproductive rights, democratic political system in Poland, women as the larger part of Polish society, norms of mutual respect on structural, legal, social, and customary levels, independence from political parties and commercial entities, private individuals, non-governmental organizations, media representatives, scientific communities, social activists, creators of culture, foreign media, politicians in general. Personal authorization was by the reerences to professor Monika Płatek, actresses Maja Ostaszewska, Magdalena Cielecka, Agnieszka Holland, Agata Kulesza, Paulina Młynarska, Małgorzata Szumowska, Juliette Binoche, Jane Birkin, Julie Delpy, Milla Jovovich, Charlotte Gainsbourg, top model Anja Rubik, singer Rita Ora, and American feminist theorist and professor of philosophy and political theory at New School for Social Research in New York Nancy Fraser.

Rationalization was by the references to the utility of the actions: organization of men and women who share common values, organization of women, unification of women of all ages from all over Poland, unification of men and women as the widespread national movement, creation of a forum for discussion, virtual space for the meetings of the women from all over the state, a platform where women have a right to speak which had been deprived of before, place where the women and men who share uniquely positive features meet, place where women show the support to others and feel supported themselves, possibility to be seen and heard, expression of anger, defense of women reproduction rights for the benefit of all Polish women, opposition to: the planned legislation, being ignored when the relevant laws are passed, hypocrisy, pregnant women being refused the healthcare services they are entitled to by the virtue of law, the real problems and challenges faced by single mothers, women living in poverty of suffering from chronic diseases being virtually ignored and neglected, threats, orders, and punishment, threatening doctors with criminal responsibility for conducting prenatal testing, fear of pregnancy, losing 
health and lives, death, violations of basic human rights of the democratic system in Poland, the clergy, oppressive state and oppressive men, the deputy Jacek Żalek ${ }^{44}$, the will to win the state where women feel safe enough to conceive, give birth to, and raise children, need for security through sex education, and for the right to self-decision making.

Narrativization was a historical summary of past events related to the change of Polish political reality. According to the founders, Gals for Gals' political activities resulted in the web meetings in which people finally could talk about their matter of interest. They also presented the history of abortion in Poland to show that in 2016, the freedom and life of women were threated more than ever. These two stories were to establish the founding myth of Gals for Gals as the movement which appeared in particularly hard times to unite people in the fight for women freedom and life.

The mentioned references are worth discussing to delve analytically into the mechanisms of self-legitimation. In the first mythopoesis strategy, the Gals told the history of the movement and concluded it with the sentence "Thus Gals for Gals have become the Internet phenomenon, a forum for discussion, and virtual space for the meetings of the women from all over the state" ${ }^{45}$. So, according to the narration, the movement provided people with the platform for debate they had never had before.

The second strategy contrasted the past and the present to show the current situation of women: „Before the political transformation, women in Poland could legally terminate pregnancies in safe conditions that did not threaten their health or life. They could decide for themselves about their bodies, whether they want to be mothers or not. In 1993, this right was taken away from them, and the binding law was called a compromise. The existence of a thriving abortion underground and abortion tourism shows that the 'abortion compromise' is fake. Women continue to interrupt pregnancies, but this is done in an atmosphere of fear and intimidation, with the risk of their health and life. Even when they are entitled to a legal

\footnotetext{
${ }^{44}$ Jacek Żalek is the representative of the conservative political party Law and Justice (Prawo i Sprawiedliwość) who strongly supported the draft act which was to have imposed a total ban on abortion.

${ }^{45}$ Gals for Gals, Co robimy?... o. c.
} 
abortion, they must go through a series of humiliations and are always dependent on someone's grace. At this point, the limited law can be taken away completely from women. Over the next few months, politicians and priests will decide for us by voting on the cruel and barbarous draft law submitted to the Sejm by the fanatics who are ready to sacrifice the freedom and life of women in the name of ideology" ${ }^{\prime 4}$. The reference to the future drew on the fear from the new abortion law to encourage activists to prevent from its advent. It was a call for action in the name of the shared pro-choice opinions and against the rejected pro-life views.

Gals for Gals rationalized their occurrence by the references to the utility of their actions: „This year's April Fool's Day proved to be far from funny for the Polish women. It was the day when the media broadcast the news about the draft novelty of the Abortion Law. The Facebook Action Group 'Gals for Gals' was initiated by the few of us the same evening, in order to express our anger and opposition towards the planned legislation and seek the support of other women. The first girls invited their female colleagues to join the group, they invited others, and so the story went... It was like an avalanche. Now, the group is over 100000 members strong, as the opposition against the planned novelty is very common. New, local action groups and campaigns are established each day" ${ }^{\$ 7}$. So, the founders indicated that the website created the place where people could share the opinion about the draft novelty. They emphasized that the movement represents a common attitude towards the draft act.

Not only the effective law did the movement consider, but also human rights: "Our group is a platform, where we, the women, have a right to speak, which we have been deprived of before. Our discussions have made us aware of our strength to take the matter in our own hands and fight for our rights. The same rights we are naturally entitled to as human beings. We have met many exceptional women and men there. This is also the place, where we could show our support to other women and feel supported

\footnotetext{
${ }^{46}$ Gals for Gals, Demonstracja „Odzyskać wybór”, April 5, 2016, [electronic version]. Available: https://www.dziewuchydziewuchom.pl/2016/04/05/demonstracja-odzyskac-wybor/ [accessed October 24, 2018].

${ }^{47}$ Gals for Gals, Co robimy?... o. c.
} 
ourselves" ${ }^{\prime 8}$. The founders introduced themselves as the opportunity to benefit from human rights that women were usually deprived of and being a part of the mutually supporting community.

The Facebook Action Group was to provide participants with the sense of community, belonging to the idea-driven group, and defending the threatened right to choose: "The participants of the Facebook Action Group Gals for Gals are men and women who think that every woman has the right to choose when the issue of pregnancy termination is concerned"49. The founders foreclosed potential arguments against joining the movement: "The Gals for Gals movement unites women of all ages, from all over Poland, who differ —often significantly — in their political and religious views; yet, what they have in common is the goal to defend women reproduction rights for the benefit of all Polish women. Many of us have never been involved in this sort of activity or expressed their views in such an explicit manner. The women, joined by many men, have been united as the 'Gals for Gals' action group, a widespread national movement" ${ }^{, 50}$. They considered themselves as the inclusive catch-all movement, which mirrors the assumption: „The organic reach of the campaign 'I support the Gals' confirmed the power of social media in building a woman's community. This action showed us much more than any surveys and opinion polls. In one day, our premonitions were confirmed... It's clear that we all are the Gals"51. The founders presented the mobilization as a successful grassroot initiative which drew on actions which united women.

The founders also referred to the need for public visibility configured with the opposition to the current situation of women: "Today, we are in the streets, so that our loud protest becomes known. Let us be seen. Let our voice be heard. We've had enough of our voice being ignored, when the laws are passed, which affect us directly. We've had enough of the hypocrisy of those in authority, who are eager to risk the lives of both mothers and children as a means to express their 'pro-life' views. We've had

\footnotetext{
${ }^{48}$ Ibid.

${ }^{49}$ Ibid.

${ }^{50} \mathrm{Ibid}$.

${ }^{51}$ Gals for Gals, \#PopieramDziewuchy Announcement... o. c.
} 
enough of pregnant women being refused the healthcare services they are entitled to by the virtue of law, even now, before any novelty is passed. When the legislation becomes stricter, our access to support services during

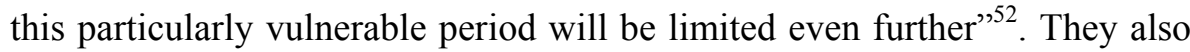
opposed the selected political subjects: „(...) the spontaneous movement Gals for Gals decided to take matters into their own hands and renounce the service of the clergy, oppressive state and oppressive men, such as deputy Żalek who is familiar with period more than feminists and non-feminists" and "We do not associate with political parties or commercial entities" The founders drew a demarcation line between the movement and other political subjects despite the potential goal community.

The opposition to the current state of Poles and the projected future displaced a constructive discussion on expectations about the abortion law. This attitude informed most of the rationalization strategies: "Above all, we've had enough of the real problems and challenges faced by single mothers, women living in poverty of suffering from chronic diseases being virtually ignored and neglected. Instead of threats, orders and punishment, give us the state where we feel safe enough to conceive, give birth to and raise our children. We've had enough of the officials threatening doctors with criminal responsibility for conducting prenatal testing. We do not want the prosecution to investigate the character of each and every miscarriage. We've had enough of this fear of pregnancy. We do not want to be afraid of losing our health and lives. No children will ever be born if we die. We've had enough of basic human laws being violated in the seemingly democratic state of Poland. We've had enough of OUR laws being violated. As professor Monika Płatek said: 'Whoever controls the reproduction of a fellow human being controls their lives. Whoever refuses a fellow human

\footnotetext{
${ }^{52}$ Gals for Gals, Co robimy?... o. c.

${ }^{53}$ Gals for Gals, Codziennik Feministyczny pisze, April 7, 2016, [electronic version]. Available: https://www.dziewuchydziewuchom.pl/2016/04/07/codziennik-feministyczny-pisze/ [accessed October 24, 2018].

${ }^{54}$ Gals for Gals, Demonstracja „Odzyskać wybór”, April 5, 2016, [electronic version]. Available: https://www.dziewuchydziewuchom.pl/2016/04/05/demonstracja-odzyskac-wybor/ [accessed October 24, 2018].
} 
being to decide about their own reproduction takes control over that individual.' We want to be back in control! Bring back our choice!"55. The movement objected to disregarding human rights considered as the fundamental characteristics of democratic regimes: "We cannot admit of further attempt to limit women freedom. In the democratic state, there is no place for disregard for fundamental human rights, in this case, the rights of the larger part of society. Women are $51.6 \%$ out of 40 millions of citizens of Poland. Ignoring our body of opinion is the violation of the norms of mutual respect on structural, legal, social, and customary levels" ${ }^{\prime 56}$. The objections justified and accounted for taking part in contentious performances: „We go out into the street because we do not accept that our bodies and our lives are decided by anyone other than us. Let's meet on Saturday 9 April at the Sejm to show how many of us want to regain the right to decide about ourselves. For too long we were told that the current solution is a 'compromise.' Let us show that we do not accept the barbaric law that puts us in the role of hostages of our pregnancies" demand for access to reproductive right: „The heart of Gals for Gals is the issue of access to the all reproductive rights. It tells that we need the possibility to decide about our fertileness. It means that we should know how to protect ourselves and have the right methods for it. Sex education is the basis of the security we fight for" $" 58$. This claim did double duty to promote the Internet-based call for action endorsed by celebrities (e.g., the top model Anja Rubik).

During mass mobilization, the Gals used the references to the celebrities who expressed support for the movement to authorize their political activity: „The opposition to the plan to introduce an almost complete ban on abortion in Poland was reported by private individuals, non-governmental

${ }^{55}$ Gals for Gals, Manifest: Przemówienie Dziewuch odczytane na demonstracji, Warszawa 2016, [electronic version]. Available: https://www.dziewuchydziewuchom.pl/o-nas/manifest/ [accessed October 11, 2018].

${ }^{56}$ Gals for Gals, Co robimy?... o. c.

${ }^{57}$ Gals for Gals, Demonstracja „,Odzyskać wybór”... o. c.

${ }^{58}$ Gals for Gals, \#sexedpl Announcement, Warszawa 2016, [electronic version]. Available: https://www.dziewuchydziewuchom.pl/sexedpl/ [accessed October 11, 2018]. 
organizations, representatives and media representatives, scientific communities, activists and social activists, female and male creators of culture. Thanks to international solidarity, it was possible to draw the attention of foreign media and politicians to the fact of a potential threat to the freedom, health, and life of Polish women. The enormous involvement of actress Maja Ostaszewska and the top model Anja Rubik helped to achieve media coverage. The support for Gals for Gals also manifested, among others, Magdalena Cielecka, Agnieszka Holland, Agata Kulesza, Paulina Młynarska, Monika Płatek, and Małgorzata Szumowska. The solidarity with Polish women expressed the actresses Juliette Binoche, Jane Birkin, Julie Delpy, Milla Jovovich, and Charlotte Gainsbourg, and singer Rita Ora. We were especially pleased with the support of Nancy Fraser, an American female feminist theorist and professor of philosophy and political theory at New School for Social Research in New York" $" 59$. The founders mentioned the names to elevate themselves as a successful initiative. They aimed also to anchor the movement in social awareness as the phenomenon appreciated by celebrities.

After the first burst of political activity, the incipient indicators of social demobilization occurred. The second period covered with the analysis begins with the submission of the first draft act and ends with the first reading of this draft act. So, the caesurae are 19th August 2016 and 23rd September 2016. Then, the third period is from the day after the first reading to the second reading of the first draft act. The caesurae of this period are 24th September 2016 and 6th October 2016. Surprisingly, Gals for Gals abandoned using self-legitimation strategies over the crucial threat situations which seemed to be the obvious incentives to protest. The founders did not take advantage of the crucial stages of the legislative process of the first draft to maintain and strengthen their collective identity. It shows that the movement's activity took the form of actions ancillary to the founders' impulses and spontaneous actions rather than was responsive to the threats.

The fourth period is from the day after the rejection of the first draft act during the second reading and the day before the submission of the second

${ }^{59}$ Gals for Gals, \#PopieramDziewuchy Announcement... o. c. 
draft act. These caesurae are 7th October 2016 and 29th November 2017. The first anniversary of the website was the incentive to resume the identityforming attempts rather than any stage of the legislative processes.

In the fourth period, Gals for Gals used the discoursive self-legitimation strategies 28 times. Not unlike the first period, the movement made use of the configuration of authorization (25\%), rationalization $(71.43 \%)$, and narrativization (3.57\%). In addition, just like the first period of political activity, they avoided treating moral evaluation as an identity-forming factor. Although similarly to the first period, authorization and rationalization were in use more frequently than mythopoesis, the type of configuration changed in the fourth period. Narrativization was kept down since its proportion only slightly increased from $2.74 \%$ to $2.74 \%$. Whereas the proportion of rationalization grew from $46.58 \%$ to $71.43 \%$, the authorization dropped from $50.68 \%$ to $25 \%$. It means that initially, the founders strived to link the movement to celebrities and human rights, and then consequently preserved the links to draw social support and appreciation. Rationalization armed activists with arguments against the current political situation and the planned law which was to have imposed a total ban on abortion. These prochoice arguments were to inform the current public debate on reproductive rights.

Just like the first period, in the fourth, the personal authorization was by the references to the top model Anja Rubik who acted as the movement's ambassador, actresses Juliette Binoche, Charlotte Gainsbourg, Milla Jovovich, and singer Rita Ora who manifested their support for the movement on the Internet. In turn, the impersonal authorization was built with respect to the Federka award, the established organization Federa, the Polish Business Council of the name of Jan Wejchert award, constitutionally secular country, and the states where activists organized demonstrations in solidarity with Poles (France, Iceland, Japan, and Mongolia).

Rationalization was by references to the dissemination of ideas, creation of the community of women, gathering female users on the Internet, the success of the viral action "I support the Gals", making space for discussion on the Internet, holding demonstrations and protests, putting pressure on politicians, volunteering in the media, opposing to the deprivation of women 
of the right to choose, to decide on their health and life, the need for the application of the effective law, respect the right of women to decide about their fertileness, democracy, freedom, and a good quality of life.

Not unlike the first period, in the fourth period, narrativization aimed to create the myth of the movement's beginning. Gals for Gals introduced the history of the unexpectedly successful union of women from all over Poland. The strategies were consistent and consolidated the idea of the unique movement which allowed women to unite in the fight for the due reproductive rights.

In the anniversary news, Gals for Gals used all the three strategies. They referred to the celebrities who endorsed them after the mass mobilization to confirm their sustained advocacy: "The Gals phenomenon is the proof of social media power to disseminate ideas and create the community of women. One year ago, when we decided to exchange opinions on the due change of the abortion law on Facebook, we did not believe that it would become the all-Polish social movement composed of almost 50 regional groups. Today, the Facebook Action Group Gals for Gals gathers over 100000 female users and the movement's female ambassador is Anja Rubik. The range of the Gals validated during the viral action 'I support the Gals' joined by international starts, including Juliette Binoche, Charlotte Gainsbourg, Milla Jovovich, and Rita Ora. Since last year, we have been creating space for discussion on the Internet, organizing demonstrations and protests, putting pressure on politicians, and volunteering in the media. Just 7 months after the foundation of the Gals for Gals group, we received the Federka, the award for activity in favor of women, from the Federa, the organization which functions for 25 years. A few days ago, Barbara Ewa Baran, one of the movement's founders, on the behalf of the Gals, won a nomination for the Polish Business Council of the name of Jan Wejchert award for social activity. Therefore, the Gals have many reasons to celebrate ${ }^{60}$. Personal and impersonal authorization served to maintain the

60 Gals for Gals, Mamy rok!, October 1, 2017, [electronic version]. Available: https://www.dziewuchydziewuchom.pl/2017/04/01/mamy-rok/ [accessed October 23, 2018]. 
identity based on celebrity endorsement and to prove that the movement had a patina of success.

Gals for Gals hyperbolized the range of support for their political activities: "From France and Iceland to Japan and Mongolia. All the world demonstrates against a total ban on abortion in Poland" solidarity demonstrations as the evidence of successful mobilization.

Just like the first period, in the fourth period, the Gals built their identity on the opposition to the current political situation and the presumed consequences of the total ban on abortion: "We act socially by drawing upon own resources as well as the help and goodwill of people who, just as we do, oppose to depriving women of the right to choose, to decide on their health and life" ${ }^{, 2}$. Noteworthy, the opposition co-occurred with demand for adherence to the law: "Great is the arrogance of those who impose on citizens in a constitutionally secular country, who and why they should give birth, and, disregarding the worldview of female and male citizens, proclaim that they are to give birth to whatever they give birth can be baptized. It is contempt and disregard for fate, health, the life of women, children, and fetuses. To change the current pathological situation, we must dun for the effective law. Let us stop inflecting the word 'abortion' and let us begin to demand respect for the law in force, that is, Law on Family Planning, Human Embryo Protection, and Conditions of Permissibility of Abortion: Act of January 7, 1993. Let us not let the lives of girls and women be limited only if the worst comes to the worst! So, how much must one be enslaved and gagged to be silent and each time to buy a cheap accusation that in revealing the facts one attacks the Church? Therefore, demanding changes which would respect the right of women to decide about their fertileness, first and foremost, at the same time, we demand the adherence to law. It is

${ }^{61}$ Gals for Gals, Od Francji i Islandii aż po Japonię i Mongolię. Cały świat demonstruje przeciwko zakazowi aborcji $w$ Polsce, October 7, 2016, [electronic version]. Available: https://www.dziewuchydziewuchom.pl/2016/04/07/od-francji-i-islandii-az-po-japonie-imongolie-caly-swiat-demonstruje-przeciwko-zakazowi-aborcji-w-polsce/ [accessed October 24, 2018].

${ }^{62}$ Gals for Gals, Wesprzyj Dziewuchy!, October 11, 2016, [electronic version]. Available: https://www.dziewuchydziewuchom.pl/2016/10/11/wesprzyj-dziewuchy/ [accessed October 24, 2018]. 
time, therefore, to ensure that the currently binding law is respected. (...) We want democracy, freedom and a good quality of life? (sic!) It is time for us to enforce the law that we have in accordance with the Family Planning Act, the right to decide about our life and fertileness" ${ }^{\prime 63}$. These authorization, rationalization, and mythopoesis strategies were coherent with selflegitimation in the first period.

The fifth period is from the submission of the second draft act to its first reading. So, the caesurae are 30th November 2017 and 10th January 2018. The external incentives which should have sparked off a reaction were erased from the discourse rather than treated as a possible means for selfpreservation, the source of unifying goals, explanation, and justification for the movement's continuance. Although the draft act's targets were contrary to the values held by Gals for Gals, its submission did not bring on any identity-forming attempts. Before the first reading, the movement's founders abandoned producing and distributing discoursive self-legitimation strategies. The administrators of the website did not see the stages of the legislative process as the potentially precarious situations. At the same, Gals for Gals failed to discuss any other issues important to the movement's participants. No attempts to maintain and strengthen social bonds indicated the beginning of demobilization processes.

The sixth period is from the day after the first reading of the second draft act to Gals for Gals' demobilization. These caesurae are 11th January 2018 and 12th April 2018. During the final stage of the movement's continuance, Gals for Gals avoided using self-legitimation strategies. Although the draft act was referred to the committees of the Sejm of the Republic of Poland, the movement did not regard it as the threat situation. During the social mobilization, Gals for Gals failed to submit their draft act and avoided developing a meaningful program to change the effective abortion law.

\footnotetext{
${ }^{63}$ Gals for Gals, Opinia Ekspertki: prof. Monika Płatek o projekcie PFROŻ, October 19, 2016, [electronic version]. Available:

https:/www.dziewuchydziewuchom.pl/2016/10/19/opinia-ekspertki-prof-monika-platek-oprojekcie-pfroz/ [accessed October 24, 2018].
} 
Table 1. The Gals for Gals' discoursive self-legitimation strategies from the movement's mobilization to demobilization

\begin{tabular}{|c|c|c|c|c|}
\hline $\begin{array}{l}\text { The strategy } \\
\text { The period of } \\
\text { occurrence }\end{array}$ & authorization & moralization & rationalization & narrativization \\
\hline $\begin{array}{l}\text { I PERIOD } \\
\text { 1st April } 2016 \\
-18 \text { th August } \\
2016\end{array}$ & 37 & 0 & 34 & 2 \\
\hline $\begin{array}{l}\text { II PERIOD } \\
\text { 19th August } \\
2016 \text {-23rd } \\
\text { September } \\
2016\end{array}$ & 0 & 0 & 0 & 0 \\
\hline $\begin{array}{l}\text { III PERIOD } \\
\text { 24th Septem- } \\
\text { ber } 2016 \text { - 6th } \\
\text { October } 2016 \\
\end{array}$ & 0 & 0 & 0 & 0 \\
\hline $\begin{array}{l}\text { IV PERIOD } \\
7 \text { th October } \\
2016-29 \text { th } \\
\text { November } \\
2017 \\
\end{array}$ & 7 & 0 & 20 & 1 \\
\hline $\begin{array}{l}\text { V PERIOD } \\
\text { 30th Novem- } \\
\text { ber } 2017 \text { - } \\
\text { 10th January } \\
2018\end{array}$ & 0 & 0 & 0 & 0 \\
\hline $\begin{array}{l}\text { VI PERIOD } \\
\text { 11th January } \\
2018-12 \text { th } \\
\text { April } 2018\end{array}$ & 0 & 0 & 0 & 0 \\
\hline
\end{tabular}

Source: own study

\section{CONCLUSIONS}

As the research shows, Gals for Gals developed their identity during the two stages of continuance. In the first period of political activity determined by the Gals for Gals mobilization and the day before the submission of the first draft act which was to have imposed a total ban on abortion in Poland, the 
founders used self-legitimation strategies 73 times. They took form of authorization $(50.68 \%)$, rationalization $(46.58 \%)$, and narrativization $(2.74 \%)$. The fourth period was from the day after the rejection of the first draft act during the second reading and the day before the submission of the second draft act. In the fourth period, Gals for Gals used the discoursive selflegitimation strategies 28 times. Not unlike the first period, the founders made use of the configuration of authorization (25\%), rationalization (71.43\%), and narrativization (3.57\%).

The strategies were consistent but not developed directly before the first and the second reading of the first draft act and the first reading of the second draft act. These external incentives neither influenced the discoursive self-legitimation strategies nor became the collective identity-forming factors. The movement was not responsive to the key stages of the legislative processes which might have been considered the obvious opportunities to maintain and develop the collective identity. Instead, the movement made identity-forming attempts directly after the mass mobilization and in its first anniversary. These activities were impulsive, action-driven, and drew upon the sense of successful mass mobilization.

The Gals for Gals website offered internally coherent and rough-andready justifications and explanations against the restriction of abortion law. The Gals' identity constantly drew upon mostly authorization, rationalization, and remotely narrativization. Authorization dominated at the beginning, but then this strategy gave place to rationalization. Initially, the Gals focused on linking the movement to celebrities and human rights, and then consequently preserved the links to gain social appreciation and support. Rationalization armed activists with arguments against the current political situation and the planned law which was to have imposed a total ban on abortion. Moralization did not enter the discourse, which reveals the absence of aspirations and inability to build an enduring movement. So, on the awareness level, the Gals built a sense of legitimacy on authorizationderived references to celebrities who endorsed the movement and human rights, the rationalization-derived utility of social action and opposition to political reality, and mythopoesis-driven stories about the Gals for Gals beginning to provide themselves with cognitive validity. 


\section{REFERENCES}

BBC, "Black Monday: Polish women strike against abortion ban", in $B B C$ October 3, 2016, [electronic version].

Available: https://www.bbc.com/news/world-europe-37540139

[accessed October 11, 2018].

T. BeAty, "Strike to Win: Can Polish Feminists Turn Protest Into Power?", in Dissent, 64/3, (2017), 125-133.

Center for Reproductive Rights, Law on Family Planning, Human Embryo Protection, and Conditions of Permissibility of Abortion Act of January 7, 1993, as amended as of December 23, 1997, New York 2018, [electronic version]. Available: https://www.reproductiverights.org/world-abortionlaws/polands-abortion-provisions [accessed October 10, 2018].

G. Edwards, Social Movements and Protest, Cambridge University Press, Cambridge and New York 2014.

N. Fairclough, Analysing Discourse: Textual Analysis for Social Research, Routledge, London and New York 2003.

Gals for Gals, \#PopieramDziewuchy Announcement, Warszawa 2016, [electronic version]. Available:

https://www.dziewuchydziewuchom.pl/popieramdziewuchy/ [accessed October $11,2018]$.

Gals for Gals, \#sexedpl Announcement, Warszawa 2016, [electronic version]. Available:

https://www.dziewuchydziewuchom.pl/sexedpl/ [accessed October 11, 2018].

Gals for Gals, \#TrudnyOkres, April 4, 2016, [electronic version]. Available:https://www.dziewuchydziewuchom.pl/2016/04/04/trudnyokres/ [accessed October 24, 2018].

Gals for Gals, Co robimy?, Warszawa 2016, [electronic version]. Available: https://www.dziewuchydziewuchom.pl/co-robimy/ [accessed October 11, 2018].

Gals for Gals, Codziennik Feministyczny pisze, April 7, 2016, [electronic version]. Available:

https://www.dziewuchydziewuchom.pl/2016/04/07/codziennik-feministycznypisze/ [accessed October 24, 2018].

Gals for Gals, Demonstracja „,Odzyskać wybór”, April 5, 2016, [electronic version]. Available: https://www.dziewuchydziewuchom.pl/2016/04/05/demonstracjaodzyskac-wybor/ [accessed October 24, 2018]. 
Gals for Gals, Dziewuchy Dziewuchom: O nas, Warszawa 2016, [electronic version]. Available: https://www.dziewuchydziewuchom.pl/ [accessed October $11,2018]$.

Gals for Gals, Mamy rok!, October 1, 2017, [electronic version]. Available: https://www.dziewuchydziewuchom.pl/2017/04/01/mamy-rok/ [accessed October 23, 2018].

Gals for Gals, Manifest: Przemówienie Dziewuch odczytane na demonstracji, Warszawa 2016, [electronic version]. Available: https://www.dziewuchydziewuchom.pl/o-nas/manifest/ [accessed October 11, 2018].

Gals for Gals, News, Warszawa 2016-2018, [electronic version]. Available: https://www.dziewuchydziewuchom.pl/news/ [accessed October 11, 2018].

Gals for Gals, Od Francji $i$ Islandii aż po Japonię $i$ Mongolię. Caty świat demonstruje przeciwko zakazowi aborcji $w$ Polsce, October 7, 2016, [electronic version].

Available:

https:/www.dziewuchydziewuchom.pl/2016/04/07/od-francji-i-islandii-az-pojaponie-i-mongolie-caly-swiat-demonstruje-przeciwko-zakazowi-aborcji-wpolsce/ [accessed October 24, 2018].

Gals for Gals, Opinia Ekspertki: prof. Monika Płatek o projekcie PFROŻ, October 19, 2016, [electronic version].

Available: https://www.dziewuchydziewuchom.pl/2016/10/19/opinia-

ekspertki-prof-monika-platek-o-projekcie-pfroz/ [accessed October 24, 2018].

Gals for Gals, Regulamin Grupy Dziewuchy Dziewuchom, Warszawa 2016, [electronic version]. Available: https://www.dziewuchydziewuchom.pl/onas/regulamin-grupy-dziewuchy-dziewuchom/ [accessed October 11, 2018].

Gals for Gals, Wesprzyj Dziewuchy!, October 11, 2016, [electronic version]. Available: https://www.dziewuchydziewuchom.pl/2016/10/11/wesprzyjdziewuchy/ [accessed October 24, 2018].

Gals for Gals, Wyślij wieszak pani premier, April 4, 2016, [electronic version]. Available: https://www.dziewuchydziewuchom.pl/2016/04/04/wyslij-wieszakpani-premier/ [accessed October 24, 2018].

H. GÁSIOROWSKA, "Women and their Rights in the Nationalists' Strategies: Abortion as a Contentious Issue in the Polish 'Culture War'”, in M. FIELITZ, L. L. LALOIRE (eds.), Trouble on the Far Right: Contemporary Right-Wing Strategies and Practices in Europe, Verlag, Bielefeld, 135-144.

B. GODZIŃSKI, “'Dziewuchy dziewuchom' oficjalnie znakiem towarowym. Inicjatorka ruchu grozi feministkom sądem", in Na Temat April 21, 2018, [electronic version]. Available: https://natemat.pl/236271,konflikt-wsrod- 
feministek-dlaczego-dziewuchy-dziewuchom-kloca-sie-o-nazwe [accessed October 11, 2018].

M. KaletZKY, R. MCGlaZer, "Migrating Tactics: An Interview with Ewa Majewska and Katarzyna Rakowska", in Critical Times: Interventions in Global Critical Theory, 1/1, 2018, 226-240. Available:

https://ctjournal.org/index.php/criticaltimes/article/view/21 [accessed October $11,2018]$.

A. KIEŁBIEWSKA, "Retoryka 'czarnego marszu' na materiale haseł prezentowanych w przestrzeni publicznej”, in Res Rhetorica, 5/3, (2018), 2-21.

E. KOROLCZUK, "Explaining mass protests against abortion ban in Poland: the power of connective action", in Zoon Politikon, 7, (2016), 91-113.

K. JaCOBSSON, E. KorolcZuK, "Preface", in K. JaCobsson, E. KorolcZUK (eds.), Civil Society Revisited: Lessons from Poland, Berghahn Books, Oxford, New York 2017, i-xi.

D. V. POLANSKA, "Polish citizens turn their back on NGOs and embrace community activism", in The Conversation, 3/3, (2017), 1-4. [electronic version]. Available: http://www.divaportal.org/smash/get/diva2:1115214/FULLTEXT01.pdf [accessed October 11, 2018].

J. RAK, Theorizing Cultures of Political Violence in Times of Austerity: Studying Social Movements in Comparative Perspective, Routledge, London and New York 2018.

SEJM RP, Obywatelski projekt ustawy o zmianie ustawy z dnia 7 stycznia 1993 r. o planowaniu rodziny, ochronie płodu ludzkiego i warunkach dopuszczalności przerywania ciaży oraz ustawy z dnia 6 czerwca 1997 r. - Kodeks karny, Warszawa 2016, [electronic version]. Available: http://www.sejm.gov.pl/sejm8.nsf/PrzebiegProc.xsp?id=6EDFF98AE25263E5 C125801400298427 [accessed October 22, 2018].

Sejm RP, Obywatelski projekt ustawy o zmianie ustawy z dnia 7 stycznia 1993 r. o planowaniu rodziny, ochronie plodu ludzkiego i warunkach dopuszczalności przerywania ciaży, Warszawa 2018, [electronic version]. Available: http://www.sejm.gov.pl/sejm8.nsf/PrzebiegProc.xsp?id=CDD22B469F73D121 C125820B0057A399 [accessed October 22, 2018].

R. SUdDABy, R. GREenWOOD, "Rhetorical Strategies of Legitimacy", in Administrative Science Quarterly, 50/1, 2005, 35-67.

CH. Tilly, Contentious Performances, Cambridge University Press, Cambridge, New York, Melbourne, Madrid, Cape Town, Singapore, São Paulo, and Delhi 2008.

Ch. Tilly, s. Tarrow, Contentious Politics, 2nd edition, Oxford University Press, New York 2015. 
E. VAARA, "Struggles over legitimacy in the Eurozone crisis: Discursive legitimation strategies and their ideological underpinnings", in Discourse \& Society, 25/4, 2014, 500-518.

T. Van Leeuwen, Discourse and Practice: New Tools for Critical Discourse Analysis, Oxford University Press, New York 2008.

T. VAN LEEUWEN, "Legitimation in discourse and communication", in Discourse \& Communication, 1/1, 2007, 91-112.

A. WIERZChOlSKA, "Gender in the resurgent Polish conservatism", in K. BlUHM, M. VARGA (eds.), New Conservatives in Russia and East Central Europe, Routledge, London, New York 2018, 198-222.

Wprost and TVP Info, "Sejm skierował projekt 'Zatrzymaj aborcję' do dalszych prac w komisjach", in Wprost January 10, 2018, [electronic version]. Available: https://www.wprost.pl/kraj/10097241/sejm-skierowal-projektzatrzymaj-aborcje-do-dalszych-prac-w-komisjach.html [accessed October 11, 2018]. 